\title{
UJI PRA KLINIS TOLERANSI GLUKOSA EKSTRAK ETANOL SERTA PENGUJIAN TOKSISITAS AKUT EKSTRAK ETANOL DARI PUGUN TANA (Picria felterrae Lour.).
}

\author{
Imam Bagus Sumantri1, Sumadio Hadisahputra1, Dharma Lindarto², Awaluddin Saragih' \\ ${ }^{1}$ Fakultas Farmasi Universitas Sumatera Utara, ${ }^{2}$ Fakultas Kedokteran Universitas Sumatera Utara \\ ibs2342@gmail.com
}

\begin{abstract}
ABSTRAK
Diabetes mellitus merupakan penyakit degeneratif yang memerlukan pengobatan yang intensif. Tanaman tradisional untuk pengobatan diabetes banyak dijumpai di masyarakat dan telah digunakan secara turun temurun. Pugun Tana (Picria felterrae Lour.) merupakan tumbuhan khas yang digunakan oleh masyarakat Dairi untuk pengobatan diabetes. Data hasil penelitian efektifitas sebagai antidiabetes dari Pugun Tana belum banyak dilakukan. Penelitian ini dilakukan bertujuan untuk menguji keamanan dan efektifitas dari Pugun Tanan sebagai antidiabetes sehingga dapat digunakan sebagai tanaman tradisional yang aman dan berkhasiat.

Penelitian ini dilakukan dengan karakteristik simplisia daun (penentuan kadar air, penentuan kadar abu total dan tidak larut dalam asam, penentuan kadar sari larut etanol dan penentuan larutan kadar sari larut air). Ekstrak dibuat dalam crude extract dengan metode maserasi-perkolasi.

Uji Toksisitas secara akut crude extract daun pugun tana tidak menunjukkan tanda-tanda keracunan dan kematian yang berarti sampai dosis $10.000 \mathrm{mg} / \mathrm{kg}$ bb. Crude extract pugun tana (Picria felterrae Lour.) dikategorikan praktis tidak toksis atau toksisitas ringan. Namun, data indeks organ menunjukkan bahwa ada perbedaan dari organ seperti hati, dan perbedaan ini tidak memberikan perbedaan yang berarti dibandingkan dengan dosis lainnya. Uji Toleransi glukosa dengan pemberian larutan glukosa dosis $5 \mathrm{~g} / \mathrm{kg}$ bb menunjukkan bahwa pemberian ekstrak etanol pugun tana dosis 50 , 100 dan $200 \mathrm{mg} / \mathrm{kg}$ BB tersebut menurunkan kadar gula darah tikus yang diberikan glukosa 50\%. Suspensi ekstrak pugun tana dosis $100 \mathrm{mg} / \mathrm{kg}$ bb memberikan penurunan kadar gula darah hampir sama dengan suspensi glibenklamid dosis $10 \mathrm{mg} / \mathrm{kg}$ bb dan kenaikan dosis ekstrak tidak memberikan efek penurunan kadar gula darah yang lebih baik.
\end{abstract}

Kata kunci: tikus obesitas, toleransi glukosa, toksisitas akut, picria felterrae, pugun tana,

\section{PRE-CLINICAL TRIAL OF TOLERANCE GLUCOSE OF ETHANOLIC EXTRACT AND ACUTE TOXICITY EFFECT TEST OF PUGUN TANA (Picria felterrae Lour.) ETHANOLIC EXTRACT}

\begin{abstract}
Diabetes mellitus is a degenerative disease that requires intensive treatment. Traditional plant treatments for diabetes are often found in public and has been used for generations. Pugun Tana (Picria felterrae Lour.) Is a typical plant used by the Dairi for the treatment of diabetes. Research data as antidiabetic effectiveness of Pugun Tana has not been done. This research was conducted aiming to test the safety and effectiveness of antidiabetic Pugun empire as it can be used as a traditional plant that is safe and efficacious.

The research was done by characteristic simplicia leaves (the determination of moisture content,ash content determination of total and insoluble in acids, determination of the ethanol-soluble extracts and determination of a solution of water-soluble levels). The extract is made in crude extract by maceration-percolation method.

Acute toxicity test of crude extract of pugun tana leaves showed no signs of poisoning and significant deaths up to a dose of $10,000 \mathrm{mg} / \mathrm{kg}$ bb. Crude extract pugun tana (Picria felterrae Lour.) Is categorized as practically non-toxic or mild toxicity. However, organ index data show that there is a difference from a liver-like organ, and this difference does not make a significant difference compared to other doses.

Glucose tolerance test with $5 \mathrm{~g} / \mathrm{kg}$ bb glucose solution showed that ethanol extract of pugun tana dose 50, 100 and $200 \mathrm{mg} / \mathrm{kg}$ BW lowered blood sugar level given 50\% glucose. Suspension of
\end{abstract}


panaun extract of $100 \mathrm{mg} / \mathrm{kg}$ bb gave a decrease in blood glucose level similar to the $10 \mathrm{mg} / \mathrm{kg}$ bw glibenclamide suspension and the increase in the dose of extract did not give a better effect of decreasing blood sugar levels.

\section{Keywords: Obese rast, tolerance glucose, acute toxicity, picria felterrae, pugun tana,}

\section{Pendahuluan}

Diabetes adalah penyakit kronik yang terjadi dikarenakan pankreas tidak memproduksi cukup insulin, atau tubuh tidak dapat bekerja secara efektif menghasilkan insulin. Insufisiensi fungsi insulin dapat disebabkan oleh gangguan atau defisiensi produksi insulin oleh sel-sel beta Langerhans kelenjar pankreas, atau disebabkan oleh kurang responsifnya sel-sel tubuh terhadap insulin. (Departemen Kesehatan RI, 2005; World Health Organization (WHO), 2008).

Hasil survei WHO, Indonesia menempati urutan ke-4 dengan jumlah penderita diabetes terbesar di dunia setelah India, Cina dan Amerika Serikat. Pravelensi penderita diabetes setiap tahun sebesar $8,6 \%$ dari total penduduk, sehingga tahun 2025 penderita diabetes di Indonesia diperkirakan meningkat 12,4 juta jiwa (Departemen Kesehatan RI, 2005). Amerika sebagai negara maju sendiri ada 23,6 juta atau $7,8 \%$ penderita diabetes dari populasi warga amerika dari anak-anak dan orang dewasa (Anonima ${ }^{\text {a }}$ 2009; National Diabetes Fact Sheet, 2007). Tahun 2008 di dunia diperkirakan 180 juta orang menderita diabetes. Jumlah tersebut akan dua kali lipatnya pada tahun 2030 sekitar 360 juta diseluruh dunia (World Health Organization (WHO), 2008). Pada tahun 2005, lebih dari 1,1 juta penderita diabetes meninggal dunia (dari data lain menyebutkan bahwa kematian akibat diabetes mendekati 2,9 juta jiwa per tahun). Kematian ini $80 \%$ berasal dari negara berkembang dan miskin dengan umur di bawah 70 tahun serta 55\% dari kematian diabetes ini adalah wanita. (World Health Organization (WHO),, 2008).

Indonesia merupakan mega-senter keragaman hayati dunia, dan menduduki urutan terkaya kedua di dunia setelah Brazilia. Jika biota laut ikut diperhitungkan, maka Indonesia menduduki urutan terkaya pertama di dunia. Sekitar 40.000 spesies tumbuhan, di mana 30.000 spesies hidup di kepulauan Indonesia. Sekurang-kurangnya 9.600 spesies tumbuhan dari 30.000 spesies berkhasiat sebagai obat dan kurang lebih 300 spesies telah digunakan sebagai bahan obat tradisional oleh industri obat tradisional (Departemen Kesehatan RI, 2007). Penggunaan sediaan herbal untuk penyakit degeneratif terus berkembang dengan pesat. Salah satu penyakit degeneratif yang banyak diteliti yaitu penyakit diabetes. Penelitian bahan alam yang potensi sebagai antidiabetes seharusnya perlu dikembangkan dari hulu ke hilir. Penelitian obat herbal yang sudah lama dikenal dan digunakan secara turun temurun secara kearifan lokal (local wisdom) perlu ditingkatkan dari segi keamanan dan khasiat sehingga penggunaanya lebih terjamin di masyarakat.

Masyarakat Tiga Lingga Kabupaten Dairi Propinsi Sumatera Utara menggunakan Pugun Tana (Pierce fel-terrae) yang merupakan salah satu tumbuhan berkhasiat sebagai antidiabetes. Secara tradisional, Masyarakat mengunyah beberapa lembar daun segar Pugun Tana untuk menurunkan kadar gula darah (antidiabetes). Tumbuhan pugun tana ini merupakan salah satu tumbuhan kearifan lokal dimana penggunaannya sebagai antidiabetes masih digunakan di daerah tersebut. Dari hasil identifikasi LIPI, nama latin dari pugun tana adalah Picria fel-terae Lour famili Scrophulariaceae. Nama lain dari spesies ini adalah Curanga fel-terrae Merr.(Anonimb, 2009) dan Curanga amara Vahl (Anonims, 2009). Di negara lain tumbuhan ini dikenal dengan nama hempedu tanah, gelumak susu, rumput kerak nasi (Malaysia), sagai-uak (Philippines), kong saden (Laos) dan thanh (Vietnam) (Anonimd, 2009). Kandungan kimia dari Pugun Tana atau Picria felterrae Merr. adalah Glukosida pahit dan curangin (Anonimc, 2009). Secara tradisional, di Maluku dan Filipina, cairan dekoksi dari tanaman ini dinggap sebagai obat cacing untuk anak-anak, dan untuk mengobati kolik (mulas mendadak dan hebat) dan malaria. Di Indonesia, tapel daun dapat menyembuhkan gatal-gatal dan penyakit kulit lainnya. Infusa dari daun bersama dengan daun kaki kuda digunakan untuk mengatasi batuk danm rasa sesak di dada. Maserasi daun dengan alkohol dianggap sebagai tonik (untuk menguatkan badan dan meningkatkan nafsu makan) (Anonimd, 2009).

Berdasarkan dari penggunaan tradisional tersebut maka perlu untuk dilakukan penelitian pembuktian khasiat daun Pugun Tana terstandar sebagai penurun kadar gula darah secara praklinis (toleransi glukosa) dengan pembanding Glibenklamid dosis $10 \mathrm{mg} / \mathrm{kg}$ bb dan menguji keamanan dengan melakukan Uji 
Toksisitas akut.

\section{Bahan dan Metode}

Penelitian yang dilakukan meliputi pengumpulan dan pengolahan simplisia daun pugun tana; penentuan standarisasi simplisia yaitu penentuan kadar air (PKA), penentuan kadar abu total dan kadar abu yang tidak larut dalam air, penentuan kadar sari larut etanol dan penentuan kadar sari larut air; pembuatan crude extract dengan cara perkolasi, Uji Toleransi Glukosa (Kadar gula darah (mg/dL)) dan; Uji toksisitas akut crude extract (Kondisi fisiologis dan kematian hewan); Analisis data dilakukan dengan menggunakan Analisis Varian (Anava).

Alat-alat yang digunakan alat - alat gelas, laboratorium (seperti beaker glass, labu takar, Erlenmeyer dan sebagainya), Blender (Panasonic), neraca Analitik listrik (Vibra), neraca hewan (Presica Geniwigher, GW-1500), Alat PK-Air (Azeotropi), rotary evaporator (Heidolph vv-2000 dan Boeco), Muffle Furnace (Noberthem) mortar dan stamper, oral sonde, spuit (ukuran $1 \mathrm{ml}$ dan $3 \mathrm{ml}$ ), kertas saring, penangas air, Easy Touch GSU Test, animal rodent restrainer, Kandang mencit dan tikus, dan kotak pengamatan transparan.

Bahan yang digunakan Daun Pugun Tana, Etanol 96\%, Metformin (Sigma), Glibenklamid (Sigma), CMC-Na, Aquadest, Larutan fisiologis $\mathrm{NaCl}$ 0,9\% (Otsuka), toluen, formalin 10\%, Strip test Easy Touch, D-Glukosa, dan bahan kimia lain.

Hewan yang digunakan dalam percobaan ini adalah mencit putih galur swiss dan Tikus putih galur wistar yang diperoleh dari Pusat Penelitian dan Pengembangan Kesehatan (Puslitbangkes) Bidang Medis dan Farmasi Jakarta. Uji antidiabetes dengan metode uji toleransi glukosa terhadap hewan obesitas. Uji toksisitas $\mathrm{LD}_{50}$ dilakukan dengan menggunakan hewan uji mencit jantan dan betina berat badan 25-30g (Angelina dkk, 2008; Gad C. Shayne, 2002). Hewan dikondisikan selama lebih kurang satu minggu di laboratorium farmakologi farmasi USU dengan diberi makanan pelet T79-4 dan minuman air mineral yang sesuai. Penelitian ini menggunakan Uji pra klinik (dengan hewan uji) sehingga pelaksanaannya terlebih dahulu telah meminta persetujuan Komite Etik Penelitian Kesehatan dari Fakultas Kedokteran, Universitas Sumatera Utara

Penyediaan Simplisia. Daun Pugun Tana diperoleh dari Desa Tiga Lingga Kabupaten Dairi. Daun dikeringkan di dalam lemari pengering dengan suhu tidak lebih dari $40^{\circ} \mathrm{C}$. Daun dikeringkan sampai didapat masa yang kering dan mudah dihancurkan. Simplisia dikarakterisasi sesuai dengan Materia Medika Indonesia edisi VI tahun 1995 dengan mengukur kadar air (PKA), kadar abu total dan larut dalam asam, serta kadar sari larut dalam air dan etanol (Depkes RI, 1995).

Pembuatan Crude Extract Etanol. Ekstrak etanol dibuat dengan melakukan ekstraksi metode perkolasi dengan Pelarut Etanol 96\%. Serbuk simplisia dimasukkan ke dalam bejana bertutup dan dibasahi dengan sejumlah cairan penyari etanol, dimaserasi selama 3 jam. Massa dipindahkan sedikit demi sedikit ke dalam perkolator, kemudian cairan penyari dituangkan secukupnya dan di atas simplisia masih terdapat selapis cairan penyari, perkolator ditutup dan dibiarkan selama 24 jam. Cairan dibiarkan menetes dengan kecepatan $1 \mathrm{ml}$ tiap menit, cairan penyari ditambahkan berulang-ulang sehingga selalu terdapat selapis cairan penyari di atas simplisia. Perkolat diuapkan menggunakan alat penguap vakum putar hingga diperoleh ekstrak kental (Sakulpanich, 2008; United State Pharmacopia (USP), 2009).

Suspensi CMC-Na 1\%. Sebanyak $500 \mathrm{mg}$ karboksil metil selulosa natrium (CMC-Na) dikembangkan dengan $10 \mathrm{ml}$ air panas di dalam lumpang, lalu digerus sampai homogen. Dituang ke dalam labu tentukur $50 \mathrm{ml}$, ditambah air suling sampai $50 \mathrm{ml}$.

Suspensi Crude Extract Pugun Tana. Suspensi Crude Extract Daun Pugun Tana dibuat dalam larutan suspensi karboksil metil selulosa natrium (CMC-Na) konsentrasi 1\%. Pengujian antidiabetes uji toleransi glukosa dibuat dalam 3 konsentrasi yaitu 0,5\%;1\% dan 2\%. Ditimbang $125 \mathrm{mg}$ (0,5\%); $250 \mathrm{mg}$ (1\%) dan $500 \mathrm{mg}$ (2\%) crude extract dilarutkan dalam suspensi konsentrasi CMC-Na 1\% secara perlahan sampai $25 \mathrm{ml}$. Pengujian antidiabetes uji induksi diabetogen aloksan dibuat crude extract konsentrasi 1\%. Pengujian keamanan (toksisitas akut) dibuat konsentrasi crude extract dalam konsentrasi berbeda untuk dosis 100; 316,2; $1.000 ; 3162 ; 10.000 \mathrm{mg} / \mathrm{kg}$ bb (Dosis pemberian $1 \mathrm{~mL} / 100 \mathrm{~g}$ berat badan (bb) hewan uji tikus, dan maksimum $5 \%$ berat badan hewan uji mencit putih) (Gad, 2002; Derelanko, 2000).

\section{Suspensi Obat Pembanding}

Glibenklamid. Serbuk glibenklamid dari Sigma dibuat dalam larutan suspensi karboksil metil selulosa ntrium (CMC-Na) konsentrasi $1 \%$. Konsentrasi glibenklamid dibuat dalam konsentrasi 0,05\% dengan menimbang 0,050 mg glibenklamid dilarutkan dalam suspensi CMC-Na 
1\% secara perlahan-lahan didalam lumpang dan dimasukkan ke dalam labu tentukur sampai 100 $\mathrm{ml}$ (Dosis pemberian $10 \mathrm{mg} / \mathrm{kg}$ bb hewan uji) (Goverdhan, 2008).

Larutan Glukosa 50\%. Larutan DGlukosa 50 gram dibuat dalam larutan aquadest $100 \mathrm{ml}$. Pemberian dosis dilakukan dengan dosis $5 \mathrm{~g} / \mathrm{kg}$ bb hewan uji.

Pengujian Antidiabetes (Toleransi Glukosa). Hewan uji tikus putih galur wistar dikondisikan dalam kandang selama 1 minggu. Makanan hewan diberikan dengan lemak tinggi dan gula tinggi. Selama pemeliharaan hewan diberikan makanan pelet T79-4. Makanan khusus dibuat dengan komposisi modifikasi yaitu: Lemak hewani kalengan Orchid Butter 20\%, kuning telur $20 \%$, Glukosa 10\%, dan Pelet T94-1 hingga 100\% (Shafrir Eleazar, 2007).

Tikus obersitas yang telah diberikan makanan selama 1-2 minggu dipuasakan selama 18 jam. Kemudian berat badan ditimbang dan diukur kadar gula darah puasa. Diberikan larutan glukosa dosis $5 \mathrm{~g} / \mathrm{kg}$ BB secara peroral. Setelah 30 menit ditentukan kadar gula darah dengan alat Easy touch.

Kemudian masing - masing tikus diberi:

Kelompok $1 \quad$ : Suspensi CMC $1 \%$ dosis 1 $\%$ bb (peroral)

Kelompok 2 : Suspensi glibenklamid dosis $10 \mathrm{mg} / \mathrm{kg}$ bb (peroral).

Kelompok 3 : Suspensi Crude Extract Daun Pugun Tana dosis 50; 100 dan $200 \mathrm{mg} / \mathrm{kg} \quad \mathrm{bb}$ (peroral).

Kelompok $4 \quad$ : Suspensi Crude Extract Daun Pugun Tana dosis 50; 100 dan $200 \mathrm{mg} / \mathrm{kg} \quad \mathrm{bb}$ (peroral).

Kelompok $5 \quad$ : Suspensi Crude Extract Daun Pugun Tana dosis 50; 100 dan $200 \mathrm{mg} / \mathrm{kg} \quad \mathrm{bb}$ (peroral).

Pengukuran kadar gula darah dilakukan pada selang waktu 30, 60, 90, dan 120 menit. Pengukuran kadar gula darah dilakukan dengan menggunakan alat easy touch GCU (Adnyana I. Ketut, 2004; Etuk, 2010).

Uji Toksisitas Akut (LD-50). Hewan uji jantan dan betina (masing-masing 5 ekor) dikondisikan selama 1 minggu dan dipuasakan sepanjang malam. Pada hari percobaan, hewan ditimbang dan ditandai. Dihitung dosis hewan uji dengan dosis terendah sampai dosis tinggi (4 rasio dosis tertentu) dan diberikan dosis tunggal secara oral (Zaini, 2005). Diamati hewan uji pada 4 jam pertama, 24 jam kemudian. Pengamatan dilanjutkan pada hari-hari berikutnya selama 7 hari pada waktu yang sama. Pengamatan yang dilakukan meliputi berat badan, keadaan fisiologis, reaksi lain seperti : kejang, dan jumlah kematian (Gad, 2007; Zaini, 2005; Angelina, 2008).

Dosis yang diberikan dalam penelitian dalam 5 dosis dengan kelompok I dosis percobaan $100 \mathrm{mg} / \mathrm{kg}$ bb (log 2) dan pengelompokan hewan uji dilakukan secara acak (random) dengan ditambah 4 kelompok untuk empat peringkat dosis 316,2;1.000;3.162 dan $10.000 \mathrm{mg} / \mathrm{kg}$ bb $(\log 2,5 ; \log 3$; $\log 3,5$; dan $\log$ 4)(Gad, 2007). Jika terjadi kematian, maka jumlah kematian hewan dan dicari dosis LD-50 dengan rumus :

Untuk LD-50:

$$
\begin{aligned}
& \mathbf{m}=\mathbf{a}-\mathbf{b}(\boldsymbol{\Sigma} \mathbf{p i - 0 , 5 )} \\
& \mathrm{m}=\text { Log LD-50 } \\
& \mathrm{a}=\text { Logaritma dosis terendah yang masih }
\end{aligned}
$$

menyebabkan jumlah kematian 100\% tiap kelompok

$\mathrm{b}=$ Beda logaritma dosis berurutan

pi = Jumlah hewan yang mati menerima

dosis i dibagi dengan jumlah seluruh yang menerima dosis $i$.

(Depkes RI, 1969)

Pada hari terakhir hewan uji dibedah dan ditimbang organ-organ pentingnya yaitu jantung, hati, dan ginjal (Angelina dkk, 2008).

Analisa Data. Rancangan penelitian yang digunakan pada penelitian ini adalah rancangan acak lengkap dengan pengujian menggunakan software SPSS versi 15. Data hasil penelitian yaitu \% kadar gula darah (\% KGD) dari Uji tolerasi glukosa, dan data \% indeks organ hewan pada uji toksisitas akut.

\section{Hasil Dan Pembahasan}

Hasil identifikasi yang dilakukan oleh Pusat Penelitian Biologi, Lembaga Ilmu Pengetahuan Indonesia (LIPI) Bogor, sampel tumbuhan adalah Picria fel-terrae Lour. famili Scrophulariaceae. Hasil Standarisasi tanaman yang dilakukan pada simplisia daun Pugun Tana (Picria felterrae Lour.) diperoleh data sebagai berikut:

a. Persentase Berat Kering Simplisia Berat basah dari Daun Segar Pugun Tana (Picria felterrae Lour.) sebanyak 5850 gram, setelah pengeringan diperoleh daun kering (simplisia kering) sebanyak 1700 gram. Persentase berat kering simplisia adalah 29,06\% dari berat basah. Crude ekstrak 
etanol yang didapat sebanyak 34,13\%.

b. Penentuan Kadar Air (PKA)

Kadar air dengan metode Azeotropi (Destilasi Toluena) dari serbuk simplisia daun yaitu 9,65\%. Kadar air dari simplisia masih memenuhi persyaratan Materia Medika Indonesia bahwa kadar air dari suatu simplisia tidak boleh lebih dari 10\% (Ditjen POM RI, 1995; WHO, 1998; 2011).

c. Penentuan Kadar abu total

Kadar abu total dengan melakukan peleburan pada suhu tinggi $\left(600^{\circ} \mathrm{C}\right)$ didapat hasil yaitu 7,34\% dan kadar abu tidak larut dalam asam sebesar 0,98\%.

d. Penentuan Kadar Sari kadar sari larut dalam air dan kadar sari larut dalam etanol.

Kadar Sari kadar sari larut dalam air didapat hasil $21,02 \%$ dan kadar sari larut dalam etanol $17,14 \%$.

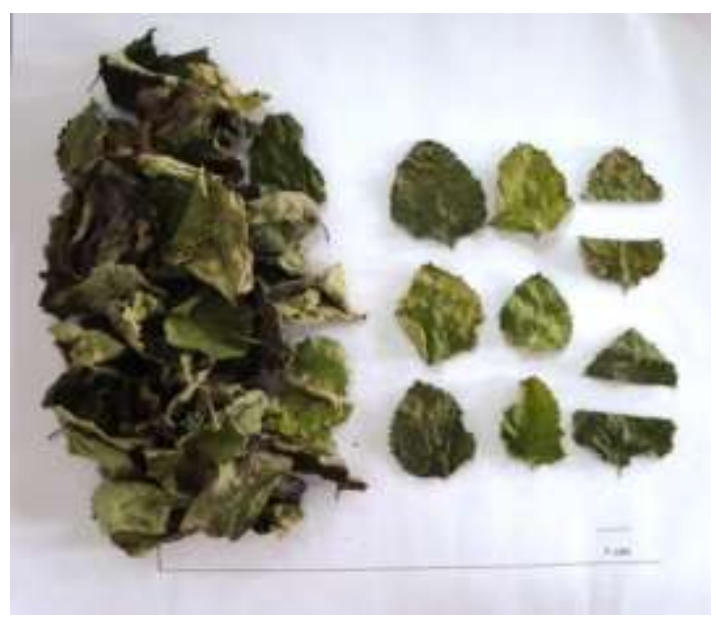

Gambar 1. Simplisia tumbuhan pugun tana

\section{Uji Toksisitas Akut (LD-50) Pengamatan Fisiologi}

Dari hasil pengamatan secara fisiologis, kondisi mencit dari dosis log 2 (100 mg/kg BB), $\log 2,5$ (316 mg/kg BB) dan log $3(1.000 \mathrm{mg} / \mathrm{kg}$ $\mathrm{BB})$ tidak menunjukkan perubahan fisiologis yang berarti secara visual (hewan masih bergerak normal dan lincah tanpa ada perubahan dari nafas, tertidur, reaktif atau terjadinya kejang). Namun, pada dosis log 3,5 (3162 mg/kg $\mathrm{BB})$ dan dosis log 4 (10.000 mg/kg BB) terjadi ada perubahan fisiologis yaitu gerak lambat dan kurangnya reaktif (hanya pada 1-4 jam pengamatan), namun kondisi hewan tidak menunjukkan perubahan yang cukup berarti (tanda-tanda toksik lain seperti tertidur, reaktif, gerak lambat sampai kejang).

\section{Pengamatan Indeks Organ Hewan}

Pemberian dosis tunggal oral ekstrak pada dosis 100, 316,2 , 1000, 3162 dan 10.000 $\mathrm{mg} / \mathrm{kg}$ bb pada tabel analisis varian (anava) memiliki perbedaan pada organ hati dan jantung dengan nilai signifikansi 0,005 pada organ jantung jantan; 0,000 pada organ hati jantan; 0,000 pada organ jantung betina dan 0,001 pada organ hati betina.

Pada organ ginjal tidak ada perbedaan yang bermakna dari kelima perlakuan dosis sehingga ekstrak tidak mempengaruhi proses ekskresi ginjal hewan uji yang betina dan jantan. Uji lanjutan (post hoc) duncan dapat dilihat dosis perbedaan pada masing organ dimana pada organ hati jantan ada perbedaan pada dosis 3.162 $\mathrm{mg} / \mathrm{kg}$ bb $(5,017)$ berbeda dengan dosis 1000 $(5,537) ; 316,2$ (5,613); $10.000(5,967) ;$ dan 100 $(6,2226) \mathrm{mg} / \mathrm{kg} \mathrm{bb}$. Organ hati betina terlihat adanya perbedaan pada dosis 1.000 dan 10.000 $\mathrm{mg} / \mathrm{kg}$ bb tidak berbeda nyata dengan dosis 316,2; 3.162 dan $100 \mathrm{mg} / \mathrm{kg}$ bb. Perbedaan ini terlihat tidak menunjukkan pada kenaikan dosis memberikan kenaikan pada indeks organ hewan sehingga efek ekstrak terhadap hati tidak bisa ditentukan.

\section{Uji Toleransi Glukosa \\ Uji Toleransi Glukosa Crude Extract}

Dari Gambar 2 dapat dilihat bahwa pemberian ekstrak etanol pugun tana dosis 50, 100 dan $200 \mathrm{mg} / \mathrm{kg}$ BB tersebut menurunkan kadar gula darah tikus yang diberikan glukosa $50 \%$. Suspensi ekstrak pugun tana dosis 100 $\mathrm{mg} / \mathrm{kg}$ bb memberikan penurunan kadar gula darah hampir sama dengan suspensi glibenklamid dosis $10 \mathrm{mg} / \mathrm{kg}$ bb. Dari gambar grafik pada gambar 4.1. bahwa dosis dinaikkan pada pemberian ekstrak tidak memberikan efek penurunan kadar gula darah yang lebih baik. 
Tabel 1. Hasil pengukuran kadar gula darah (KGD)

\begin{tabular}{|c|c|c|c|c|c|}
\hline \multirow[t]{2}{*}{ Perlakuan } & \multirow{2}{*}{$\begin{array}{c}\text { KGD } \\
\text { Normal }\end{array}$} & \multicolumn{4}{|c|}{ Kadar Gula Darah (KGD) mg/dL } \\
\hline & & 30 menit & 60 menit & 90 menit & 120 menit \\
\hline $\begin{array}{l}\text { Kontrol (CMC } 1 \\
\%)\end{array}$ & $\begin{array}{c}120,33 \pm \\
7,37\end{array}$ & $240,17 \pm 38,23$ & $249,17 \pm 42,74$ & $202 \pm 46,37$ & $152,5 \pm 24$ \\
\hline $\begin{array}{l}\text { Glibenklamid } \\
\text { Dosis } 10 \mathrm{mg} / \mathrm{kg} \\
\text { BB }\end{array}$ & $\begin{array}{c}100,25 \pm \\
12,89\end{array}$ & $226,5 \pm 28,58$ & $182 \pm 30,26$ & $146,5 \pm 33,79$ & $87,92 \pm 17,77$ \\
\hline $\begin{array}{l}\text { Ekstrak Etanol } \\
\text { Pugun Tana Dosis } \\
50 \text { mg/kg BB }\end{array}$ & $\begin{array}{c}131,75 \pm \\
18,09\end{array}$ & $236,83 \pm 28,36$ & $171,33 \pm 32,57$ & $137,92 \pm 12,04$ & $119,17 \pm 3,49$ \\
\hline $\begin{array}{l}\text { Ekstrak Etanol } \\
\text { Pugun Tana Dosis } \\
100 \text { mg/kg BB }\end{array}$ & $\begin{array}{c}150,67 \pm \\
27,28\end{array}$ & $201,67 \pm 6,31$ & $139,75 \pm 12,57$ & $129,17 \pm 5,84$ & $104,08 \pm 9,09$ \\
\hline $\begin{array}{l}\text { Ekstrak Etanol } \\
\text { Pugun Tana Dosis } \\
200 \text { mg/kg BB }\end{array}$ & $\begin{array}{c}137,08 \pm \\
22,86\end{array}$ & $219 \pm 45,55$ & $168,33 \pm 16,07$ & $210,58 \pm 15,13$ & $119,67 \pm 23,75$ \\
\hline
\end{tabular}

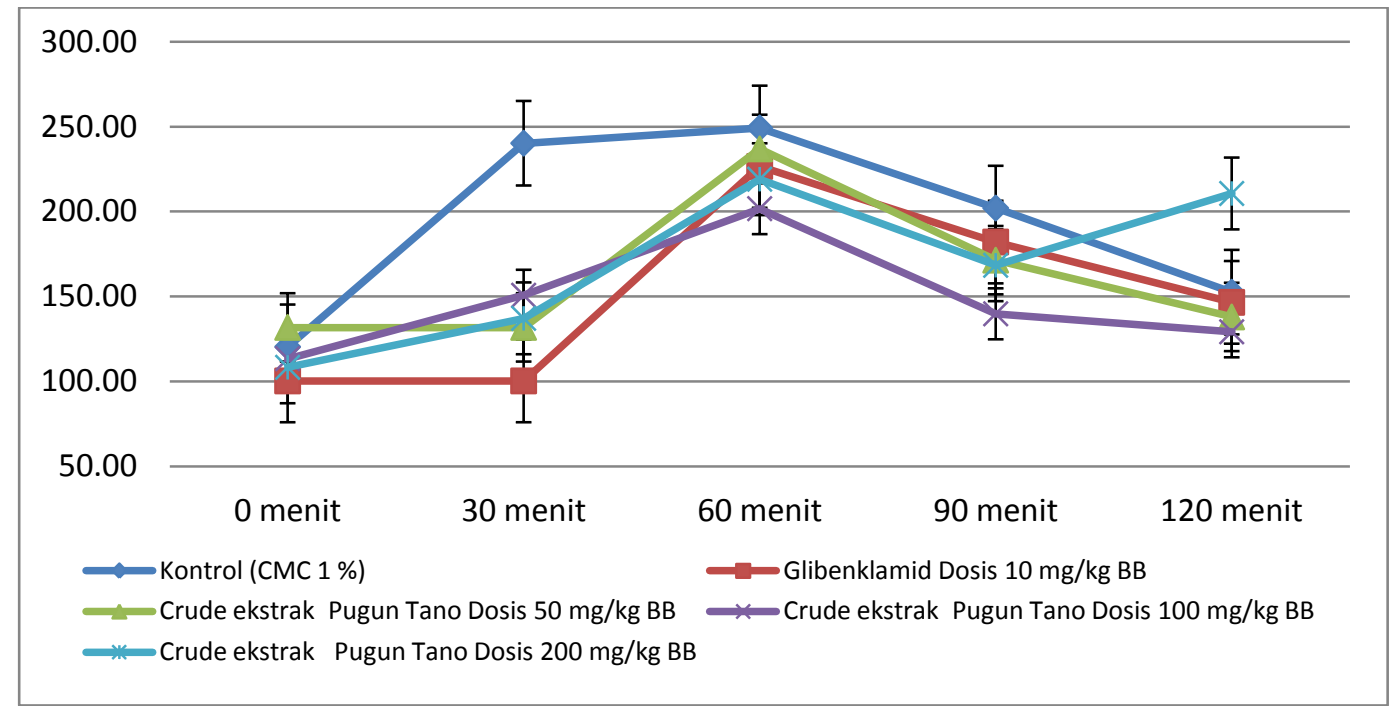

Gambar 2. Grafik Penurunan Kadar Gula Darah Ekstrak Etanol

Hasil pengujian statistik terhadap ekstrak etanol pugun tana dosis 50,100, dan 200 $\mathrm{mg} / \mathrm{kg}$ BB menunjukkan adanya perbedaan (Nilai Sig. 0.000) pada menit 60, 90 dan $120(\mathrm{P}<0,2)$. Hasil analisa statistik uji beda rata-rata duncan menunjukkan bahwa kadar gula darah tikus pada menit ke-60 dengan pemberian suspensi glibenklamid tidak berbeda secara signifikan dengan suspensi ekstrak uji dosis 50 dan 200 $\mathrm{mg} / \mathrm{kg}$ BB. Penurunan ekstrak etanol dosis 100 $\mathrm{mg} / \mathrm{kg}$ BB memberikan perbedaan dengan suspensi glibenklamid. Hasil analisa statistik uji beda rata-rata Duncan pada menit ke-90 dengan pemberian suspensi glibenklamid tidak berbeda secara signifikan dengan suspensi ekstrak uji dosis 50 dan $100 \mathrm{mg} / \mathrm{kg}$ BB. Penurunan ekstrak etanol dosis 50 dan $100 \mathrm{mg} / \mathrm{kg}$ BB memberikan perbedaan dengan suspensi ekstrak etanol dosis $200 \mathrm{mg} / \mathrm{kg}$ BB. Hasil analisa statistik uji beda rata-rata Duncan pada menit ke-120 Suspensi ekstrak dosis $100 \mathrm{mg} / \mathrm{kg}$ BB dibandingkan dengan pemberian suspensi glibenklamid tidak berbeda secara signifikan. Penurunan ekstrak etanol dosis 50 dan $100 \mathrm{mg} / \mathrm{kg}$ BB memberikan hasil yang lebih baik dari penurunan suspensi ekstrak etanol dosis $200 \mathrm{mg} / \mathrm{kg} \mathrm{BB}$.

Hasil pemeriksaan skrining fitokimia menunjukkan bahwa keduanya mengandung 
senyawa kimia golongan alkaloida, flavonoida, tanin dan steroid/triterpenoid (Juwita N, 2009). Senyawa-senyawa golongan terpenoid dan flavanoid dapat memberikan efek antidiabetes. Senyawa flavonoida yang dapat bersifat sebagai antidiabetes karena flavonoid mampu berperan sebagai senyawa yang dapat menetralkan radikal bebas, sehingga dapat mencegah kerusakan sel beta pankreas yang memproduksi insulin (Singab et.al, 2005).

\section{Kesimpulan}

Hasil pemeriksaan karakterisasi simplisia daun pugun tana diperoleh kadar air 9,65\%, kadar abu total 7,34\%, kadar abu tidak larut dalam asam 0,81\%, kadar sari larut dalam air $21,02 \%$ dan kadar sari larut dalam etanol $17,14 \%$.

Uji Toksisitas secara akut (LD-50) Ekstrak etanol daun pugun tana tidak menunjukkan tanda-tanda keracunan dan kematian yang berarti sampai dosis tertinggi uji $10.000 \mathrm{mg} / \mathrm{kg}$ BB. Ekstrak etanol pugun tana (Picria felterrae Lour.) dikategorikan praktis tidak toksis atau toksisitas ringan. Namun, dari data indeks organ menunjukkan bahwa ada perbedaan dari organ seperti hati, dan perbedaan ini tidak signifikan dibandingkan dengan dosis lainnya.

Uji Toleransi glukosa menunjukkan bahwa dosis $100 \mathrm{mg} / \mathrm{kg}$ BB pada crude ekstrak memberikan efek penurunan yang berarti secara statistik dibandingkan dengan obat pembanding glibenklamid dosis $10 \mathrm{mg} / \mathrm{kg} \mathrm{BB}$.

\section{Ucapan Terimakasih}

Terima kasih sebesar-besarnya kepada Drs. Awaluddin Saragih, M.Si., Apt. yang telah membantu peneliti dalam kegiatan penelitian ini yang dikerjasamakan dalam penelitian SP3T Provinsi Sumatera Utara.

\section{Daftar putaka}

Adhyana I Ketut, Yulinah Elin, Andreanus A.S., Endang K, Maria Immaculata, Joseph I. Sigit, Suwendar. 2004. Uji Aktivitas Antiduabetes Ekstrak Etanol Buah Mengkudu (Morinda citrifolia L.). Acta Pharmaceutical Indonesia. Vol. XXIX. No.2.2004-43.

Angelina Marrissa, Sriu Hartati, Indah D. Dewijanti, Sofina D.S., Lin Meilawati. 2008. Penentuan $L D_{50}$ Daun Cinco (Cyclea barbata Miers.) Pada Mencit. Makara Sains. Vol. 12. No. 1. April 2008; 23-26.
Anonim A. 2009. All About Diabetes. Available from: http://www.diabetes.org/aboutdiabetes.jsp. Pada 26 Maret 2009.

Anonim B. 2009. Curangga fel-terrae. From: http://www.zipcodezoo.com/plant/c/ curangga_fel-terrae. Diunduh pada tanggal: 5 Mei 2009.

Anonim C. 2009. Curanga fel-terrae (Lour.) Merr. SAGAI-USAK.

From:htttp://www.bpi.da.gov.ph.publicati ons/mp/pdf/s/sagai-usak.pdf. Diunduh pada tanggal 5 Mei 2009.

Anonim D. 2009. Picria fel-terrae. Dari: http:// www.proseanet.org/prohati4/printer.php?photoid $=459$.

Anonim E. 2009. Gestational Diabetes. From: http://www.diabetes.org/Gestationaldiabetes.jsp. Diunduh pada tanggal 26 Mei 2009.

Anonim F. 2009. Pre-Diabetes. From: www.diabetes.org/pre-diabetes.jsp. Diunduh pada tanggal 26 Mei 2009.

Anonim G. 2009. Tumbuhan Obat. Dari: http://www.kehati.or.id/Florakita browser.php?pcategory=8\&page. Diunduh pada tanggal 5 Mei 2009.

Canadian Centre for Occupational Health and Safety. 2005. LD50 and LC50. Diunduh dari http://www.ccohs.ca/oshanswers/chemic als/ld50.html\#tphp. Pada tanggal 05 Januari 2010.

Depkes RI. 1979. Farmakope Indonesia. Edisi III. Depkes RI. Jakarta.

Depkes RI. 2005. Jumlah Penderita Diabetes Indonesia Ranking ke-4 Di Dunia. Pusat Data dan Informasi Departemen Kesehatan RI. Tanggal: 05 September 2005. Dari; htttp://www.depkes.go.id/ index.php?option=news\&task= viewarticle.

Depkes RI. 2000. Parameter Standar Umum Ekstrak Tumbuhan Obat. Cetakan Pertama. Jakarta : Departemen Kesehatan RI. Hal. 10-11.

Ditjen POM. 1995. Materia Medika Indonesia. Jilid VI. Jakarta : Departemen Kesehatan RI. Hal. 536-540.

Dorelanko J. Michael. (2000). Toxicologists Pocket Handbook. CRC Press. Florida. Page. 14.

Etuk, E.U. (2010). Animals Models For Studying Diabetes Mellitus. Agriculture And Biology Journal Of North America. Agric. Biol. J. N. Am., 2010, 1(2): 130-134

Gad C. Shayne. (2002). Drug Safety Evaluation. John Wiley and Sons Inc. New York. Page 130-132. 
Goverdhan P., Rani MS., Thirupathi K., Rani S., Sathesh S., Kumar Ravi B., Mohan KG. (2008). Hypoglicemic and Antihyperglicemic Effect of Aristolochia Indica Normal and Alloxan Induceed Diabetic rats. Pharmacologyonline 1: 2029.

Shafrir Eleazar. 2007. Animal Models of Diabetes: Frontiers in Research. Second Edition. CRC Press. New York.

Singab AN. et al. 2005. Hypoglycemic effect of Egyptian Morus alba root bark extract: Effect on diabetes and lipid peroxidation of streptozotocin-induced diabetic rats. Journal of Ethnopharmacology 100: 333338.

US Pharmacopeia. 2009. Poin 565 Botanical Extract. http://www.pharmacopeia.cn/v29240/us p29nf24s0 c565.html tanggal 05 Februari 2012.

WHO. 2008. Diabetes. World Health Organization (WHO) Media Center, November 2008. From: http:// www. WHO.int/mediacentre/factsheets/fs312. Diunduh pada tanggal 11 Maret 2009.

WHO. 2011. Quality control methods for medicinal plant materials. Update dari 1998. Printed WHO, England.

Zaini Mohd Bin Asmawi. 2005. Toxicological Report on Acute Oral and Acute Dermal Toxicity of Diquat in Rats. School of Pharmaceutical Sciences. Universiti Sains Malaysia. Penang. 